\title{
In the Empire of Images: \\ Preface to the Tenth Anniversary Edition
}

\author{
For Cassie
}

In our Sunday news. With our morning coffee. On the bus, in the airport, at the checkout line. Sharing our day off from work, from school, illicit and delicious with us under the quilt. Or domestic company, out of the corner of the eye as we fold the laundry in front of the television. It may be a 5 A.M. addiction to the glittering promises of the infomercial: the latest in fat-dissolving pills, miracle hair restoration, make-up secrets of the stars. Or a glancing relationship while waiting at the dentist, trying to distract from the impending root canal. Or a luscious, shiny pile, a deliberate splurge, a can't-wait-to-get-home-with-you devotion. A teen magazine: tips on how to dress, how to wear your hair, how to make him want you. A movie seen at the theater, still large and magical in the dark. The endless commercials and advertisements we believe we pay no attention to.

Constant, everywhere, no big deal. Like the water in the goldfish bowl, barely noticed by inhabitants. Or noticed, but dismissed: "Eye Candy"-a harmless indulgence. They go down so easily, in and out, digested and forgotten. Hardly able anymore to rouse our indignation.

Just pictures.

\section{"NO ONE GETS SICK FROM LOOKING AT A PICTURE": CROSS-CULTURAL SNAPSHOTS}

The young girl stands in front of the mirror. Never fat to begin with, she's been on a no-fat diet for a couple of weeks and has reached her goal weight: 115 pounds, at 5-foot-4-exactly what she should weigh, according to her doctor's chart. But goddamnit, she still looks dumpy. She can't shake her mind free of the "Lady Marmalade" video from Moulin Rouge. Christina Aguilera, Pink, L'il Kim, 
and Mýa, each one perfect in her own way: every curve smooth and sleek, lean-sexy, nothing to spare. Self-hatred and shame start to burn in the girl, and other things too. When the video goes on, the singers' bodies are like magnets for her eyes; she feels like she's in love with them. But envy tears at her stomach, is enough to make her sick. She'll never look like them, no matter how much weight she loses. Look at that stomach of hers, see how it sticks out? Those thighs-they actually jiggle. Her butt is monstrous. She's fat, gross, a dough girl.

Frontline asked Alexandra Shulman, editor of British Vogue, if the fashion industry felt any responsibility for creating the impossibleto-achieve images that young girls measure themselves against. Shulman shrugged. "Not many people have actually said to me that they have looked at my magazine and decided to become anorexic." 1

Is it possible that Shulman actually believes it works that way?

In Central Africa, ancient festivals still celebrate voluptuous women. In some regions, brides are sent to fattening farms, to be plumped and massaged into shape for their wedding night. In a country plagued by AIDS, the skinny body has meant-as it used to mean among Italian, Jewish, and Black Americans-poverty, sickness, death. "An African girl must have hips," says dress designer Frank Osodi. "We have hips. We have bums. We like flesh in Africa." For years, Nigeria sent its local version of beautiful to the Miss World Competition. The contestants did very poorly. Then a savvy entrepreneur went against local ideals and entered Agbani Darego, a light-skinned, hyper-skinny beauty. (He got his inspiration from M-Net, the South African network seen across Africa on satellite television, which broadcasts mostly American movies and television shows.) Agbani Darego won the Miss World Pageant, the first Black African to do so. Now, Nigerian teenagers fast and exercise, trying to become "lepa" - a popular slang phrase for the thin "it" girls that are all the rage. Said one: "People have realized that slim is beautiful." 2

Brenda Richardson and Elane Rehr, authors of 101 Ways to Help Your Daughter Love Her Body, tell the story of the newly arrived Rus- 
sian immigrants Sasha, thirty-two, and her fourteen-year-old sister. Sasha, who immediately lost twenty pounds, became disgusted with her little sister's upper arms and thighs. "My little sis has fleshy arms and thighs ribboned with cellulite," she told Richardson, and complained that their mother was dressing her in shortsleeved dresses. When her mother did this, Sasha tried to stop her, telling her sister to "cover up her fat."

Rent a Russian movie made before the doors to U.S. culture were flung open; look at the actresses' arms. You'll see just how extraordinary-and how illuminating-this one little anecdote is. ${ }^{4}$

I was intrigued when my articles on eating disorders began to be translated, over the past few years, into Japanese and Chinese. Among the members of audiences at my talks, Asian women had been among the most insistent that eating and body image weren't problems for their people, and indeed, my initial research showed that eating disorders were virtually unknown in Asia. But when, this year, a Korean translation of Unbearable Weight was published, I felt I needed to revisit the situation. I discovered multiple reports on dramatic increases in eating disorders in China, South Korea, and Japan. "As many Asian countries become Westernized and infused with the Western aesthetic of a tall, thin, lean body, a virtual tsunami of eating disorders has swamped Asian countries," writes Eunice Park in Asian Week magazine. Older people can still remember when it was very different. In China, for example, where revolutionary ideals once condemned any focus on appearance and there have been several disastrous famines, "little fatty" was a term of endearment for children. Now, with fast food on every corner, childhood obesity is on the rise, and the cultural meaning of fat and thin has changed. "When I was young," says Li Xiaojing, who manages a fitness center in Beijing, "people admired and were even jealous of fat people since they thought they had a better life.... But now, most of us see a fat person and think 'He looks awful.' "'5

Because of their remote location, the Fiji islands did not have access to television until 1995, when a single station was introduced. It broadcasts programs from the United States, Great Britain, and Australia. Until that time, Fiji had no reported cases of eating disorders, and a study conducted by the anthropologist Anne Becker 
showed that most Fijian girls and women, no matter how large, were comfortable with their bodies. In 1998, just three years after the station began broadcasting, 11 percent of girls reported vomiting to control weight, and 62 percent of the girls surveyed reported dieting during the previous months.

Becker was surprised by the change; she had though that Fijian cultural traditions, which celebrate eating and favor voluptuous bodies, would "withstand" the influence of media images. Her explanation for the Fijians' vulnerability? They were not sophisticated enough about media to recognize that the television images were not "real."6

\section{"REALITY" IN THE EMPIRE OF IMAGES}

Are we sophisticated enough to recognize that the images are not "real"? Does it matter?

In the charming L.A. Story, Steve Martin asks Sarah Jessica Parker why her breasts feel so funny to the touch. "Oh, that's because they're real," she replies. It's funny. But it's also no longer a jokebecause real breasts are the anomaly among actresses and models nowadays, with consequences that extend beyond the wacky culture of celebrity-bodies. Many young men can't get aroused by breasts that don't conform to Hollywood standards of size and firmness. Do they care that those centerfold breasts aren't "real"? No. Nor do the more than 215,000 women who purchased breast implants in 2001..$^{7}$ Breast enhancement is one of the most common surgical procedures for teenagers. ${ }^{8}$ These girls are not superficial creatures who won't be satisfied unless they look like goddesses. More and more, girls who get implants feel that they need them in order to look normal in a culture in which "normal" is being radically redefined, not only by the images but by the surgeons. A cosmetic surgeon's ad in the Lexington Herald Journal: "Certainly, models and entertainers have breast augmentation, but the typical patients are women that you see every day. Your neighbors. Your co-workers. They could even be you."

In Unbearable Weight, I describe the postmodern body, increasingly fed on "fantasies of rearranging, transforming, and correcting, limitless improvement and change, defying the historicity, the mor- 
tality, and, indeed, the very materiality of the body. In place of that materiality, we now have cultural plastic."

When I wrote these words, the most recent statistics, from 1989, listed 681,000 surgical procedures performed.

In 2001, 8.5 million procedures were performed. 9

They are cheaper than ever, safer than ever, and increasingly used, not for correcting major defects, but for "contouring" the face and body. Plastic surgeons seem to have no ethical problem with this. "I'm not here to play philosopher king," says Dr. Randal Haworth in a Vogue interview; "I don't have a problem with women who already look good who want to look perfect." 10 Perfect. When did "perfection" become applicable to a human body? The word suggests a Platonic form of timeless beauty-appropriate for marble, perhaps, but not for living flesh. We change, we age, we die. Learning to deal with this is part of the existential challenge-and richness - of mortal life. But nowadays, those who can afford to do so have traded the messiness and fragility of life, the vulnerability of intimacy, the comfort of human connection, for fantasies of limitless achievement, "triumphing" over everything that gets in the way, "going for the gold." The Greeks called it hubris. We call it our "right" to be all that we can be.11

What Haworth isn't saying, too, is that the bar of what we consider "perfection" is constantly being raised-by cultural imagery, by the surgeon's own recommendations, and by eyes that become habituated to interpreting every deviation as "defect." Ann, a prospective patient described in the same Vogue article, has a welltoned body of 105 pounds but is obsessed with what she sees as grotesque fat pockets on her inner thighs. "No matter how skinny I get, they get smaller but never go away," she complains. It's unlikely that Ann, whom Haworth considers a perfect candidate for liposuction, will stop there. "Plastic surgery sharpens your eyesight," admits a more honest surgeon, "You get something done, suddenly you're looking in the mirror every five minutes-at imperfections nobody else can see."12

Where did Ann get the idea that any vestige of fat must be banished from her body? Most likely, it wasn't from comparing herself to other real women, but to those computer-generated torsos-in ads for anti-cellulite cream and the like-whose hips and thighs and buttocks are smooth and seamless as gently sloping sand- 
dunes. No actual person has a body like that. But that doesn't matter-because our expectations, our desires, our judgments about bodies, are becoming dictated by the digital. When was the last time you actually saw a wrinkle - or cellulite—or a drooping jowlor a pore or a pucker-in a magazine or video image? Ten years ago Harper's magazine printed the invoice Esquire had received for retouching a cover picture of Michelle Pfeiffer. The picture was accompanied by copy that read: "What Michelle Pfeiffer needs ... is absolutely nothing." What Pfeiffer's picture alone needed to appear on that cover was actually $\$ 1,525$ worth of chin trimming, complexion cleansing, neck softening, line removal, and other assorted touches.

\section{That was then.}

Now, in 2003, virtually every celebrity image you see-in the magazines, in the videos, and sometimes even in the movies-has been digitally modified. Virtually every image. Let that sink in. Don't just let your mind passively receive it. Confront its implications. This is not just a matter of deception-boring old stuff, which ads have traded in from their beginnings. This is perceptual pedagogy, How to Interpret Your Body 101. These images are teaching us how to see. Filtered, smoothed, polished, softened, sharpened, re-arranged. And passing. Digital creations, visual cyborgs, teaching us what to expect from flesh and blood. Training our perception in what's a defect and what is normal.

Are we sophisticated enough to know the images are not "real"? Does it matter? There are no disclaimers on the ads: "Warning: This body is generated by a computer. Don't expect your thighs to look this way." Would it matter to Ann if there were? Who cares about reality when beauty, love, acceptance beckon? Does sophistication have anything to do with it?

\section{A SAD CONFIRMATION}

When I wrote Unbearable Weight, it was widely believed that privileged white girls had the monopoly on eating and body-image problems. The presumption was a relic of the old medical models, which accepted the "profile" presented by the typical recipient of 
therapy-who was indeed largely white and upper middle classas definitive, and which failed to recognize the central role of media imagery in "spreading" eating and body-image problems across race and class (and sexual orientation). Like the Black Africans and the Fijians and the Russians (and lesbians and Latins and every other "subculture" boasting a history of regard for fleshy women), African Americans were believed "protected" by their alternative cultural values. And so, many young girls were left feeling stranded and alone, dealing with feelings about their bodies that they weren't "supposed" to have, as they struggled, along with their white peers, with unprecedented pressure to achieve, and watched Janet Jackson and Halle Berry shrink before their eyes.

Many medical professionals, too, were trapped in what I'd call the "anorexic paradigm." They hadn't yet understood that eating problems take many different forms and inhabit bodies of many different sizes and shapes. Binge eating - a chronic problem among many African American women-is no less a disordered relation to food than habitual purging, and large women who don't or won't diet are not necessarily comfortable with their bodies. Exercise addiction is rarely listed among the criteria for eating problems, but it has become the weight control of choice among a generation emulating Jennifer Lopez's round, tight buns rather than Kate Moss's skeletal collarbones. Just because a teenager looks healthy and fit does not mean that she is not living her life on a treadmillmetaphorically as well as literally-which she dare not step off lest food and fat overtake her body.

Until recently, most clinicians were not receptive to the arguments of feminists like Susie Ohrbach (and later, myself) that "body image disturbance syndrome," binge/purge cycling, "bulimic thinking," and all the rest needed to be understood as much more culturally normative than generally recognized. They wanted to draw a sharp dividing line between pathology and normality-a line that can be very blurry when it comes to eating and body-image problems in this culture. And while they acknowledged that images "play a role," they clung to the notion that only girls with a "predisposing vulnerability" get into trouble. Trained in a medical model which seeks the cause of disorder in individual and family pathology, they hadn't yet understood just how powerful, ubiquitous, and invasive the demands of culture are on our bodies and souls. 
Families matter, of course, and so do racial and ethnic traditions. But families exist in cultural time and space-and so do racial groups. Thus, no one lives in a bubble of self-generated "dysfunction" or permanent immunity-especially today, as mass media culture increasingly has provided the dominant "public education" in our children's lives. The "profile" of girls with eating problems is dynamic, not static; heterogeneous, not uniform. Therapists now report treating the anorexic daughters of anorexics, and are coming to realize the role parents play, not just in being "over-controlling" or overly demanding of their children, but in modeling obedience to cultural norms. And the old generalizations about race and "fat acceptance," while perhaps valid for older generations of Black Americans, do not begin to adequately describe the complex and often conflicted attitudes of younger people, many of whom are aware of traditional values but constantly feel the pull of contemporary demands. While working on Unbearable Weight, I called up organizations devoted to Black women's health issues, asking for statistics and clinical anecdotes, and was told: "That's a white girl's thing. African American women are comfortable with their bodies." For twenty-something Tenisha Williamson, who suffers from anorexia, such notions are almost as oppressive as her eating disorder: "From an African American standpoint," she writes, "we as a people are encouraged to 'embrace our big, voluptuous bodies.' This makes me feel terrible because I don't want a big, voluptuous body! I don't ever want to be fat-ever, and I don't ever want to gain weight. I would rather die from starvation than gain a single pound. [This makes me feel like] the proverbial Judas of my race ... and so incredibly shallow."13

In fact, the starving white girls were just the forward guard, the miners' canaries warning of how poisonous the air was becoming for everyone. I could see it in the magazines, the videos, and in my students' journals. I could see it, as I write in "Material Girl," in the transformations of Madonna and other performers of Italian, Jewish, and African American descent who seemed, at the start of their careers, to represent resistance to the waifs and willows but who just couldn't hold out against what, indeed, had begun to look like a tsunami, a cultural tidal wave of obsession with achieving a disciplined, normalized body.

It became a central argument of Unbearable Weight that eating 
disorders, analyzed as a social formation rather than personal pathology, represented a "crystallization" of particular currents, some historical and some contemporary, within Western culture. Western philosophy and religion, to begin with, have a long history of anxiety about the body as a source of hungers, needs, and physical vulnerabilities always threatening to spin out of control. But maintaining some zone of comfort with the body's needs is especially difficult in our own time. Consumer culture continually excites and encourages us to "let go," indulge in our desires-for sugar, fat, sex, mindless entertainment. But at the same time, burgeoning industries centered on diet, exercise, and body enhancement glamorize selfdiscipline and code fat as a symbol of laziness and lack of willpower. It's hard to find a place of moderation and stability in all this, easy to fall into disorder. For girls and women, the tensions of consumer capitalism are layered, additionally, with the contradictions of being female in our time. These contradictions, I argued, are succinctly embodied in the slenderness ideal. On the one hand, the lean body represents a rejection of the fifties ideal of cuddly, reproductive womanhood, and an assertion of a post-feminist, nondomestic identity. On the other hand, the steadily shrinking space permitted the female body seemed expressive of discomfort with greater female power and presence.

One of the hardest challenges I faced, in presenting these ideas at conferences and public lectures, was getting medical professionals and academics to take cultural imagery seriously. Most clinicians, unaccustomed to viewing images as anything other than "mere fashion," saw cultural interpretation as somehow minimizing the seriousness of eating disorders. I insisted-an argument I laid out explicitly in a later book, Twilight Zones-that images of slenderness are never "just pictures," as the fashion magazines continually maintain (disingenuously) in their own defense. Not only are the artfully arranged bodies in the ads and videos and fashion spreads powerful lessons in how to see (and evaluate) bodies, but also they offer fantasies of safety, self-containment, acceptance, immunity from pain and hurt. They speak to young people not just about how to be beautiful but about how to become what the dominant culture admires, how to be cool, how to "get it together." To girls who have been abused they may speak of transcendence or armoring of toovulnerable female flesh. For racial and ethnic groups whose bodies 
have been marked as foreign, earthy, and primitive, or considered unattractive by Anglo-Saxon norms, they may cast the lure of assimilation, of becoming (metaphorically speaking) "white."

Academics, on their part, were not hostile to interpretation but to what they saw as my suppression of racial and ethnic "difference." As I saw my argument, I was calling attention to a discernable historical development-the spread of normalizing imagery across race and nationality. "Difference" was being effaced, indeed. But it was mass popular culture that was effacing it, not me. Today, the evidence of this is indisputable. There is no denying that there are still racial differences in attitudes toward eating, dieting, body aesthetics. But even more dramatic are the generational differences, which show that "comfort with the body" is fast becoming a relic of another era, irrespective of race or nationality. ${ }^{14}$ The mythology persists, of course; it's a big ingredient in a certain kind of ethnic pride. So, Jennifer Lopez and Beyoncé Knowles insist they are happy with their bodies, bragging about their bodacious bottoms. "Us sisters have padding back there," says Beyoncé. "Being bootylycious is about being comfortable with your body." But sexy booty is okay, apparently, only if it's high and hard, and if other body-parts are held firmly in check. Beyoncé is comfortable with her body because she works on it constantly. On the road, she does five hundred situps a night, and Jennifer ("One of the most driven people I've ever seen," according to her personal trainer) does ninety minutes of hard training "at least" four times a week. ${ }^{15} \mathrm{Her}$ truly voluptuous Selena body is a thing of the distant past. J.Lo and Beyoncé are "fullfigured" only if Lara Flynn Boyle is your yardstick.

And then there are the men and boys, who once seemed so immune. If ever there was confirmation that eating and body image problems are products of culture, they are surely it. Women, studies always showed, are chronically dissatisfied with themselves. But ten years ago men tended, if anything, to see themselves as better looking than they (perhaps) actually were. Straight guys were proud of their beer bellies. "Do I look like I care?" was the manly way to be. Body-sculpting? Very sexually suspect. Dieting? The average, white, heterosexual guy would no more be seen at Weight Watchers than in a feather boa. The "one" in "Pepsi One" was created to sell men a diet drink without having to call it that.

And then, as I chronicle in The Male Body, the diet industries, the 
cosmetics manufacturers, and the plastic surgeons "discovered" the male body. With so much money to be made, why did it take so long? Arguably, manufacturers and advertisers feared that anxiety about being seen as gay would prevent heterosexual men from showing too obvious an interest in their bodies. African American athletic superstars like Michael Jordan and hip-hop performers like Puff Daddy (Sean P. Diddy) Combs did a lot to change that. They made jewelry, high fashion, strutting one's stuff into a macho thing. But designer Calvin Klein broke the biggest barrier. He brought the sinuous, sculpted male body out of the closet, and made everyone, gay and straight, male and female, succumb to its classic, masculine beauty. I remember the first time I saw one of his underwear ads. No male waif, the model's body projected strength, solidity. But his finely muscled chest was not so overdeveloped as to suggest a sexuality immobilized-like Schwarzenegger's, say-by the thick matter of the body. He didn't stare at the viewer challengingly, belligerently ("Yeah, this is an underwear ad and I'm half-naked. But I'm still the one in charge here. Who's gonna look away first?"). No, this model's languid body-posture, eyes downcast but not closed, offered itself nonaggressively to the gaze of another. Feast on me; I'm here to be looked at.

Today, men no longer think of personal care or taking pleasure in one's clothing, one's body, one's beauty in the eyes of another as feminine things. But basking in the admiration of the gaze, as men are finding out, requires committed bodily upkeep. This is consumer culture, after all. It can never have too much of a good thing. It thrives on our capacity for excess; it wants us to not be able to stop. Today, the athletic, muscular male body that Calvin first plastered all over buildings, magazines, and subway stops has become an aesthetic requirement, for straights as well as gays. "No pecs, no sex," is how the trendy David Barton gym sells itself: "My motto is not 'Be healthy'; it's 'Look better naked,' " Barton says. ${ }^{16}$

And now, young guys are looking in their mirrors, finding themselves soft and ill defined, no matter how muscular they are. Now they are developing the eating and body image disorders that we once thought only girls had. Now they are abusing steroids, measuring their own muscularity against the oiled and perfected images of professional athletes, bodybuilders, Men's Health models. Now the industries in body enhancement-cosmetic surgeons, manufac- 
xxiv

turers of anti-aging creams, spas and salons-are making huge bucks off men, too.

Now, too, that boys and men are developing body-image problems, feminist cultural arguments-unacknowledged-seem to have finally won the day. Psychologists are producing pictures demonstrating the increasing lean, muscular proportions of toys like G.I. Joe, illustrating their studies with photos of "steroided" centerfolds, and reassuring readers that even the most "well-adjusted men" are at risk. Say the authors of The Adonis Complex (all medical professionals): "Men could be relieved of much suffering if they could only be liberated from society's unrealistic ideals of what they should look like."17

I agree, of course. But I can't help but think of all the guilt and shame that girls, women, and their families have suffered, as our body disorders have been trivialized and pathologized over the years. It's time we made it decisively clear that "well-adjusted" girls and women are at risk, too. That no racial or ethnic group is invulnerable. That body insecurity can be exported, imported, and marketed across the globe-just like any other profitable commodity.

\section{AGING IN THE EMPIRE OF IMAGES}

They carded me until I was thirty-five. Even when I was forty-five, people were shocked to hear my age. Young men flirted with me, even at fifty. Having hated my face as a child-bushy red hair, freckles, Jewish nose-I was surprised to find myself fairly pleased with it as an adult. Then, suddenly, it all changed. The women at the make-up counter no longer compliment me on my skin. Men don't catch my eye with playful promise in theirs.

I'm fifty-six. The magazines tell me that at this age, a woman can still be beautiful. But they don't mean me. They mean Cher, Goldie, Faye, Candace. Women whose jowls have disappeared as they've aged, whose eyes have become less droopy, lips grown plumper, foreheads smoother with the passing years. They mean Susan Sarandon, who looked older in 1991's Thelma and Louise than she does in her movies today. "Aging beautifully" used to mean wearing one's years with style, confidence, and vitality. Today, it means not appearing to age at all. And-like breasts that defy gravity-it's becoming a new bodily norm. 
Greta Van Susterin: former CNN legal analyst, forty-seven years old. When she had a face-lift, it was a real escalation in the stakes for ordinary women. She had a signature style: no bullshit, downto-earth lack of pretense. (During the O.J. trial, she was the only white reporter many Blacks trusted.) Always stylishly dressed and coiffed, she wasn't really pretty. No one could argue that her career was built on her looks. Perhaps quite the opposite. She sent out a subversive message: brains and personality still count, even on television.

When Greta had her face lifted, another source of inspiration and hope bit the dust. The story was on the cover of People, and folks tuned in to her new show on Fox just to see the change-which was significant. But at least she was open about it. The beauties never admit they've had "work." Or if they do, it's vague, nonspecific, minimizing of the extent. Cher: "If I'd had as much plastic surgery as people say, there'd be another whole person left over!"18 Okay, so how much have you had? The interviewers accept the silences and evasions. They even embellish the lie. How many interviews have you read which began: "She came into the restaurant looking at least twenty years younger than she is, fresh and relaxed without a speck of make-up."

This collusion, this myth, that Cher or Goldie or Faye Dunaway, unaltered, is "what fifty-something looks like today" has altered my face, however-and without benefit of surgery. By comparison with theirs, it has become much older than it is.

My expression now appears more serious, too (just what a feminist needs), thanks to the widespread use of botox. "It's now rare in certain social circles," a New York Times reporter observed, "to see a woman over the age of 35 with the ability to look angry." 19 This has frustrated some film directors, like Baz Luhrman (who did Moulin Rouge). "Their faces can't really move properly," Luhrman complained. ${ }^{20}$ Last week I saw a sign in the beauty parlor where I get my hair cut. "Botox Party! Sign Up!" So my fifty-six-year-old forehead will now be judged against my neighbor's, not just Goldie's, Cher's, and Faye's. On television, a commercial describes the product (which really is a toxin, a dilution of botulism) as "botox cosmetic." No different from mascara and blush, it's just stuck in with a needle and makes your forehead numb.

To add insult to injury, the rhetoric of feminism has been picked 
up to help advance and justify the industries in anti-aging and body alteration. Face-lifts, implants, and liposuction are advertised as empowerment, "taking charge" of one's life. "I'm doing it for me"-the mantra of the talk shows. "Defy your age!"-Melanie Griffith, for Revlon. We're making a revolution, girls. Get your injection and pick up a sign!

Am I immune? Of course not. My bathroom shelves are cluttered with the ridiculously expensive age-defying lotions and potions that constantly beckon to me at the Lancome and Dior counters. I want my lines, bags, and sags to disappear, and so do the women who can only afford to buy their alpha-hydroxies at K-Mart. There's a limit, though, to what fruit acids can do. As surgeons develop ever more extensive and fine-tuned procedures to correct gravity and erase history from the faces of their patients, the difference between the cosmetically altered and the rest of us grows more and more dramatic.

"The rest of us" includes not only those who resist or are afraid of surgery but the many people who cannot afford basic health care, let alone aesthetic tinkering-not even of the K-Mart variety. As celebrity faces become increasingly more surreal in their wideeyed, ever-bright agelessness, as Time and Newsweek (and Discover and Psychology Today) proclaim that we can now all "stay young forever," the poor continue to sag and wrinkle and lose their teeth. ${ }^{21}$ But in the empire of images, where even people in the news for stock scandals or producing septuplets are given instant digital dental work for magazine covers, ${ }^{22}$ this is a well-guarded secret. The celebrity testimonials, the advertisements, the beauty columns all participate in the fiction that the required time, money, and technologies are available to all. ${ }^{23}$

\section{GROWING UP FEMALE IN THE EMPIRE OF IMAGES}

Here's how I can tell the ages of audience members at the talks I give: My generation (and older) still refers to "air-brushing." Many still believe it is possible to "just turn off the television." They are scornful, disdainful, sure of their own immunity to the world I talk about. No one really believes the ads, do they? Don't we all know these are just images, designed to sell products? Scholars in the au- 
dience may trot out theory about cultural resistance and "agency." Men may insist that they love fleshy women.

Fifteen years ago, I felt very alone when my own generation said these things; it seemed that they were living in a different world from the one I was tracking and that there was little hope of bridging the gap. Now, I simply catch the eye of a twenty-year-old in the audience. They know. They understand that you can be as cynical as you want about the ads-and many of them are-and still feel powerless to resist their messages. They know, no matter what their parents, teachers, and clergy are telling them, that "inner beauty" is a big laugh in this culture.

In their world, there is a size zero, and it's a status symbol. The chronic dieters have been at it since they were eight and nine years old. "Epidemic of eating disorders" is old stuff; being preached to about it turns them right off. Their world is one in which the anorexics swap starvation diet tips on the Internet, participate in group fasts, offer advice on how to hide your "ana" from family members, and share inspirational photos of emaciated models. But full-blown anorexia has never been the norm among teenage girls; the real epidemic is among the girls with seemingly healthy eating habits, seemingly healthy bodies, who vomit or work their butts off as a regular form of anti-fat maintenance. These girls not only look "normal" but consider themselves normal. The new criterion circulating among teenage girls: If you get rid of it through exercise rather than purging or laxatives, you don't have a problem. Theirs is a world in which groups of dorm girls will plough voraciously through pizzas, chewing and then spitting out each mouthful. Do they have a disorder? Of course not-look, they're eating pizza.

Generations raised in the empire of images are both vulnerable and savvy. They snort when magazines periodically proclaim (about once every six months, the same frequency with which they run cover stories about "Starving Stars") that in the "new Hollywood" one can be "Sexy at Any Size." They are literati, connoisseurs of the images; they pay close attention to the pounds coming and goingon J.Lo, on Reese, on Thora, on Christina Aguilera, on Beyoncé. They know that Kate Winslett-whom director James Cameron called "Kate Weighs-a-lot" on the set of Titanic-was described by the tabloids as "packing on," "ballooning to," "swelling to," "shooting up 
to," "tipping the scales at" a "walloping," "staggering" weight-of 135. That slender Courtney Thorne Smith, who played Calista Flockhart's friend/rival on Ally McBeal, quit the show because she could no longer keep up with the pressure to remain as thin as David Kelly wanted them to be. That Missy Elliot and Queen Latifah are not on diets just for reasons of health.

I track the culture of young girls today with particular concern, because I'm a mother now. My four-year-old daughter is a superb athlete with supreme confidence in her body, who prides herself on being able to do anything the boys can do-and better. When I see young girls being diminished and harassed by the culture it feels even more personal to me now. I'm grateful that there's a whole new generation of female athletes to provide inspiration and support for girls like Cassie. That our icons are no longer just tiny gymnasts, but powerful soccer, softball, and tennis players, broad-shouldered track stars. Mia Hamm, Sarah Walden, Serena Williams, Marion Jones. ${ }^{24}$ During a recent visit to a high school, I see how the eyes of a fourteen-year-old athlete shine as she talks about what Marion Jones means to her. In this young girl I see my own daughter, ten years from now, and I'm filled with hope.

But then, I accidentally tune in to the Maury (Povich) show, and my heart is torn in two. The topic of the day is "back-to-girl" makeovers. One by one, five beautiful twelve-, thirteen-, and fourteen-year-old "tomboys" (as Maury called them) are "brought back to their feminine side" (Maury again) through a fashion makeover. We first see them in sweatshirts and caps, insisting that they are as strong as any boy, that they want to dress for comfort, that they're tired of being badgered to look like girls. Why, then, are they submitting to this one-time, on-air transformation? To please their moms. And indeed, as each one is brought back on stage, in full make-up and glamour outfit, hair swinging (and in the case of the Black girls, straightened), striking vampy supermodel "power" poses, their mothers sob as if they had just learned their daughters' cancers were in remission. The moms are so overwhelmed they don't need more, but Maury is clearly bent on complete conversion: "Do you know how pretty you are?" "Look how gorgeous you look!" "That guy in the audience-he's on the floor!" "Are you going to dress like this more often?" Most of the girls, unsurprisingly, say yes. It's been a frontal assault; there's no room for escape. 
As jaded as I am, this Maury show really got to me. I want to fold each one of the girls in my arms and get her out of there. Of course, what I really fear is that I won't be able to protect Cassie from the assault. It's happening already. I watch public television kids' shows with her, and can rarely find fault with the gender-neutral world they portray. We go to Disney movies and see resourceful, spirited heroines. Some of them, like the Hawaiian girls in Lilo and Stitch, even have thick legs and solid bodies. But then, on the way home from the movies, we stop at MacDonald's for a Happy Meal, and-despite the fact that Cassie insists she's a boy and wants the boy's toy, a hot wheels car-she is given a box with a little miniBarbie in it. Illustrating the box is Barbie's room, and my daughter is given the challenging task of finding all the matching pairs of shoes on the floor.

Later that day, I open a Pottery Barn catalogue, browsing for ideas for Cassie's room. The designated boy's room is all in primary colors, the bedspread dotted with balls, bats, catching mitts. The caption reads: "I play so many sports that it's hard to pick my favorites." Sounds like my daughter. On the opposite page, the girls' room is pictured, a pastel planetary design. The caption reads: "I like stars because they are shiny." That, too, sounds like my daughter. But Pottery Barn doesn't think a child can inhabit both worlds. If their catalogues were as segregated and stereotyped racially as they are by gender, people would boycott.

I rent a video-Jimmy Neutron, Boy Genius-for Cassie. It's marketed as a kids' movie; it's on that wall at Blockbuster. And the movie is okay, for the most part. But then we get to the music video, which follows the movie, unaccompanied by any warnings. It's a group I've never heard of, singing a song called "Kids in America." Two of the girls are thirteen. Two are fifteen and one is sixteen. I know this because their ages are emblazoned across the screen, as each makes her appearance. They are all in full vixen attire, with professionally undulating bodies, professionally madeup, come-hither eyes.

Why are we told their ages, I wonder? Are we supposed to be amazed at the illusion of womanhood created by their performance? Or is their youth actually supposed to make it all right to show this to little kids? A way of saying "It's only make believe, only a dress-up game"? How long ago was it that an entire culture 
was outraged over clips of Jon Benet Ramsey, performing femininity in children's beauty pageants? In 2002, toddler versions of Britney Spears were walking the streets on Halloween night. Can it really be that we now think dressing our daughters up like tiny prostitutes is cute? That's what Sharon Lamb, author of The Secret Lives of Girls, thinks. She advises mothers to chill out if their nineyear-old girls "play lovely little games in high heels, strip teasing, flouncing, and jutting their chests out," to relax if their eleven-yearolds go out with "thick blue eye shadow, spaghetti straps and bra straps intertwined, long and leggy with short black dresses." They are "silly and adorable, sexy and marvelous all at once," she tells us, as they "celebrate their objectification," "playing out male fantasies ... but without risk." 25

Without risk? I have nothing against dress-up. But flouncing is one thing; stripteasing is another. Thick blue eye shadow in mommy's bathroom is fine; an eleven-year-old night on the town is not. Reading those words "without risk," I want to remind Sharon Lamb that 22 to 29 percent of all rapes against girls occur when they are eleven and younger. ${ }^{26}$ We might like to think that these rapes are the work of deranged madmen, so disconnected from reality as to be oblivious to the culture around them. Putting vast media energy into a so-called epidemic of girl-snatching, such as we witnessed during the summer of 2002, helps sustain that myth and lets us believe that we are doing all we need to do to protect our daughters if we simply teach them not to take candy or go into cars with strangers.

The reality is, however, that young girls are much more likely to be raped by friends and family members than by strangers and that very few men, whether strangers or acquaintances, are unaffected by having a visual culture of nymphets prancing before their eyes, exuding a sexual knowledge and experience that preteens don't really have. Feminists used to call this "rape culture." We never hear that phrase anymore, do we?

\section{HOPE AND FEAR}

Still, progressive forces are not entirely asleep in the empire of images. I think of $Y M$ teen magazine, for example. After conducting a survey which revealed that 86 percent of its young readers were dissatisfied with the way their bodies looked, $Y M$ openly declared 
war on eating disorders and body-image problems, instituting an editorial policy against the publishing of diet pieces and deliberately seeking out full-size models-without "marking" them as such-for all its fashion spreads. ${ }^{27}$ I like to think this resistance to the hegemony of the fat-free body may have something to do with the fact that the editors are young enough to have studied feminism and cultural studies while they got their B.A.'s in English and journalism. ${ }^{28}$

Most progressive developments in the media, of course, are driven by market considerations rather than social conscience. So, for example, the fact that 49 million women are size twelve or over is clearly the motive behind new, flesh-normalizing campaigns created by "Just My Size" and Lane Bryant. ${ }^{29}$ These campaigns proudly show off unclothed zaftig bodies and, unlike older marketing to "plus-size" women, refuse to use that term, insisting (accurately) that what has been called "plus size" is in fact average. It's a great strategy for making profits (I know they've got my ten bucks), but a species of resistance nonetheless. "I won't allow myself to be invisible anymore," these ads proclaim, on our behalf. "But I won't be made visible as a cultural oddity or a joke, either, because I'm not. I'm the norm."

The amorality of consumer capitalism, in its restless search for new markets, new ways to generate and feed desire, has also created a world of racial representations that are far more diverse now than when I wrote Unbearable Weight. This is another issue that has acquired special meaning for me, because my daughter is biracial, and I am acutely aware of the world that she sees and what it is telling her about herself. Leafing through current magazines, noting the variety of skin tones, noses, mouths depicted there, I'm glad, for the moment, that Cassie is growing up today rather than in the seventies, when Cheryl Tiegs ruled. It's always possible, of course, to find things that are still "wrong" with these representations; racist codes and aesthetics die hard. The Jezebels and geishas are still with us, and although Black male models and toddlers are allowed to have locks and "naturals," straight hair-straighter nowadays than I ever thought it was possible for anyone's hair to be-seems almost a mandatory aesthetic for young Black women. ${ }^{30}$

It's easy, too, to be cynical. Today's fashionable diversity is brought to us, after all, by the same people who brought us the 
hegemony of the blue-eyed blonde and who've made wrinkles and cellulite into diseases. It's easy to dismiss fashion's current love affair with full lips and biracial children as ethnic chic, fetishes of the month. To see it all as a shameless attempt to exploit ethnic niches and white beauty-tourism. Having a child, however, has given me another perspective, as I try to imagine how it looks through her eyes. Cassie knows nothing about the motives of the people who've produced the images. At her age, she can only take them at face value. And at face value, they present a world which includes her, celebrates her, as the world that I grew up in did not include and celebrate me. For all my anger and cynicism and frustration with our empire of images, I cannot help but be grateful for this.

On good days, I feel heartened by what is happening in the teen magazines and in the Lane Bryant and "Just My Size" ads. Perhaps advertisers are discovering that making people feel bad about themselves, then offering products which promise to make it all better, is not the only way to make a buck. As racial representations have shown, diversity is marketable. Perhaps, as Lane Bryant and others are hoping, encouraging people to feel okay about their bodies can sell products too. Sometimes, surveying the plastic, digitalized world of bodies that are the norm now, I am convinced that our present state of enchantment is just a moment away from revulsion, or perhaps simply boredom. I see a twenty-something woman dancing at a local outdoor swing party, her tummy softly protruding over the thick leather belt on her low-rider jeans. Not taut, not toned, not artfully camouflaged like some unsightly deformity, but proudly, sensuously displayed, reminding me of Madonna in the days before she became the sinewy dominatrix. Is it possible that we are beginning to rebel against the manufactured look of celebrity bodies, beginning to be repelled by their armored "perfection"?

These hopeful moments, I have to admit, are fleeting. Usually, I feel horrified-and afraid for my daughter. I am sharply aware that expressing this horror openly nowadays is to run the risk of being thought a preachy prude, relic of an outmoded feminism. At talks to young audiences, I try to lighten my touch, celebrate the positive, make sure that my criticisms of our culture are not confused with being anti-beauty, anti-fitness, or anti-sex. But I also know that when parents and teachers become fully one with the culture, children are abandoned to it. I don't tell them to love their bodies or 
turn off the television-useless admonitions today, and ones I cannot obey myself. But I do try to provide a disruption, if only temporary, of their everyday immersion in the culture. For just an hour or so, I won't let it pass itself off simply as "normalcy."

The lights go down, the slides go up. Much bigger than they appear in the magazines, but also, oddly brought down to size. For just a moment, we confront how bizarre, how impossible, how contradictory the images are. We laugh together over Oprah's head digitally grafted to another women's body, at the ad for breast implants in which the boobs stick straight up in the air. We gasp together as the before and after photos of Jennifer Lopez are placed side by side. We cheer for Marion Jones's shoulders, boo the fact that WNBA Barbie is just the same old Barbie, but with a basketball in her hand. For just a moment, we are in charge of the impact the faked images of "perfect" bodies have on us.

We look at them together and share--just for a moment-outrage.

\section{ACKNOWLEDGMENTS}

I am especially indebted to my sister, Binnie Klein, who collaborated with me on research and brain-storming for Size Fourteen, a book that we've yet to write but that informs much of this preface. Binnie also provided detailed comments on several drafts, as did Althea Webb and Leslie Heywood; their suggestions, insights, and support were invaluable. Leslie, Binnie, and Althea, along with my husband, Edward Lee, have been my constant companions in the fascinating, challenging - and often infuriating - business of trying to understand and make one's way in this culture. Thanks also to Ellen Rosenman and Lara Baker Sedlaczek for extremely helpful suggestions, to Lara for fabulous assistance in gathering international studies and other research materials, to Virginia Blum for conversations about cosmetic surgery that began many years ago and continue today, and to the faculty and students at Babson College, Indiana University, Vanderbilt University, Moorehead State College, College of Saint Rose, University of Kentucky, and Emma Willard School for discussions following my talk "Beauty 2002: An Illustrated Journey through the Innovations, Oddities, and Obsessions of Our Culture." 


\section{NOTES}

1. PBS Frontline show "Fat." Online discussion at http://pbs.org/ wgbh/pages/frontline/shows/fat/etc/press.html.

2. Norimitsu Onishi, "Globalization of Beauty Makes Slimness Trendy," New York Times, Oct. 3, 2002 (http://www.nytimes.com/2002/10/o3/ international/africa/03NIGE.html). For more on the spread of eating and body-image disorders in Africa, see Suzan Chala, "Dying to Stay Thin," The Teacher (http://www.teacher.co.za/cms/article_2002_04_29_0257.html); Mark Stuart Ellison, "Anorexia and Women of Color," Suite101.com (http://www.suite101.com/article.cfm/anorexia/45443); "Eating Disorders Rise in Zulu Women," BBC News, Nov. 4, 2002 (http://news.bbc.co.uk/2/ low/africa/2381161.stm); "Anorexia Found in Rural Africa," BBC News, July 5, 2000 (http://news.bbc.co.uk/2/hi/health/818725.stm).

3. Brenda Lane Richardson and Elane Rehr, 101 Ways to Help Your Daughter Love Her Body (New York: Harper and Row, 2001), p. xx.

4. For more on eating and body-image disorders among immigrants, see Emily Wax, "Immigrant Girls Suffer from Anorexia," Washington Post, Mar. 12, 2000 (http://www.detnews.com/2000/nation/o003/12/A14-14421 .htm); "Immigrant Girls Are Starving to Be American," Tulsa World, Sept. 16, 2002; "Immigrant Women and Eating Disorders," Colours of Ana website (http://www.coloursofana.com/r4.asp). This website provides a great deal of information on eating disorders and many different racial and ethnic groups, as well as compelling and illuminating personal stories.

5. Reported in Elizabeth Rosenthal, "Beijing Journal: China's Chic Waistline: Convex to Concave," New York Times, Dec. 9, 1999. For more on eating and body-image disorders among Asians and Asian Americans, see Eunice Park, "Starving in Silence," Asian Week, June 15-21, 2000; "Anorexia, Bulimia Rates Have Soared in Japan," Reuters Health, Sept. 25, 2001; "Asian Women and Eating Disorders," Colours of Ana website (http:// www.coloursofana.com/r2.asp); Ellen Kim, "Asian Americans and Eating Disorders: A Silent Struggle," Seattle Post-Intelligencer, Jan. 28, 2003; Sing Lee, Y. Y. Lydia Chan, and L. K. George Hsu, "The Intermediate-Term Outcome of Chinese Patients with Anorexia Nervosa in Hong Kong," American Journal of Psychiatry 160 (May 2003): 967-972.

6. Reported in Nancy Snyderman, The Girl in the Mirror (New York: Hyperion, 2002), p. 84 .

7. "Women and Cosmetic Surgery," Women's Health Project (http:// www.nowfoundation.org/issues/health/whp/whp_fact1.html).

8. Richardson and Rehr, 101 Ways, p. 223.

9. Galina Espinoza and Mike Neil, "About Face," People Magazine, Oct. 28, 2002, p. 53.

10. Sarah Brown, "Addicted to Lipo," Vogue, Oct. 2002, pp. 368, 370.

11. See "Braveheart, Babe, and the Contemporary Body," in Susan Bordo, Twilight Zones: The Hidden Life of Cultural Images from Plato to O.J. 
(Berkeley and Los Angeles: University of California Press, 1997), for elaboration of these ideas.

12. Bordo, Twilight Zones, p. 45.

13. From the Colours of Ana website (http://www.coloursofana .com/ss8.asp). For more on African Americans and eating and body-image disorders, see Marian Fitzgibbon and Melinda Stolley, "Minority Women: The Untold Story," Nova Online, http://www.pbs.org/wgbh/nova/thin/ minorities.html; Liz Dittrich, "About-Face Facts on Socioeconomic Status, Ethnicity, and the Thin Ideal," About Face Online, http://dev.about-face .org/r/facts/ses.html; Mashadi Mataban, "Invisible Women, Silent Suffering," Diversity or Division? Race, Class and America at the Millennium (http://journalism.nyu.edu/pubzone/race_class/eating.htm); Ruth StriegelMoore et al., "Eating Disorders in White and Black Women," American Journal of Psychiatry 160 (July 2003): 1326-1331.

14. Studies demonstrating this include research on Hawaiians, Hispanics, Native Americans, Jewish Americans, Indians, Argentineans, Mexican Americans, Alaskan natives, and Russians, in addition to the studies specifically cited above on Asians and Asian Americans, Africans, African Americans, immigrant populations, and Fijians.

15. Reported by Andrea Sattinger, "The Bod Squad," Teen People, Nov. 2002, pp. 108-116.

16. Reported in Dan Shaw, "Mirror, Mirror," New York Times, May 29, 1994, p. 6. See Susan Bordo, The Male Body: A New Look at Men in Public and in Private (New York: Farrar, Straus and Giroux, 1999), especially "Beauty Rediscovers the Male Body," for extended discussion of these developments.

17. Harrison Pope, Katharine Phillips, and Roberto Olivardia, The Adonis Complex: The Secret Crisis of Male Body Obsession (New York: The Free Press, 2000), p. 149.

18. Reported in Liz Smith, "What Cher Wants," Good Housekeeping, Nov. 2002, p. 112.

19. Alex Kuczynski, "Frowns Are Victims of Progress in Quest for Wrinkle-Free Look," New York Times, Feb. 7, 2002, p. A1.

20. Ibid., p. A26.

21. Fitness is class-biased, too, of course. Oprah presents each new diet and exercise program she embarks on as an inspiration for her fans. But how many of them have the money for a gym membership, let alone a personal trainer? How many even have the time to go to the gym? Magazines engage in debates about high-protein versus low-fat diets, as though our nation's "epidemic of obesity" can be solved by nutritional science. But high-quality, low-fat protein is expensive. So are fresh fruits and vegetables, and, unless you have the time to shop frequently, they are highly perishable. Millions of Americans exist on fatty, fried, carb-loaded fast food because it's the cheapest way to feed their families.

22. For those who were attentive, an unintentional visual exposé was provided when Newsweek decided to "fix" the crooked teeth of Bobbi 
xxxvi In the Empire of Images

McCaughey (mother of the McCaughey septuplets) for their cover-while Time neglected to.

23. See "Braveheart, Babe, and the Contemporary Body," in Bordo, Twilight Zones, for extended discussions of cosmetic surgery and other forms of body alteration.

24. See Leslie Heywood and Shari Dworkin, Built to Win: The Female Athlete as Cultural Icon (Minneapolis: University of Minnesota Press, 2003), for the definitive work on these developments.

25. Sharon Lamb, The Secret Lives of Girls (New York: The Free Press, 2001), pp. 42, 43.

26. Cited in Rosalind Wiseman, Queen Bees and Wannabees (New York: Crown, 2002), p. 285.

27. Teen People and Seventeen have followed suit.

28. Thanks to Julie Childers for suggesting this explanation to me.

29. The average sixteen-year-old girl is 5-foot-4 and 135 pounds, and she wears a size ten to fourteen. See Kari Haskell, "Sizing Up Teenagers," New York Times, Oct. 13, 2002.

30. Many people, of course, no longer find this "politically" problematic. With a pre-schooler who is already finding fault with her hair, I worry. 